\title{
The Stability and Cell Content of Penicillinase Messenger RNA in Bacillus licheniformis
}

\author{
By J. W. DA VIES \\ Department of Molecular Biology, University of Edinburgh, \\ King's Buildings, Edinburgh $\mathrm{EH}_{9} 3 \mathrm{JR}$ \\ (Accepted for publication 21 August 1969)
}

\begin{abstract}
SUMMARY
The stability of penicillinase messenger RNA has been assessed from the kinetics of enzyme production after inhibition of RNA synthesis with actinomycin or rifampicin. An average messenger half-life of $4.7 \mathrm{~min}$. is indicated, both for induced Bacillus licheniformis 749, and the constitutive mutant 749/C. Although this value is twice that estimated for average total m-RNA by similar techniques, there is no indication of a 'long-lived messenger' as previously implicated in other reports. An attempt was made to estimate the content of penicillinase messenger from data on the level of penicillinase made per bacterium, the polysome size, the messenger half-life and the total level of unstable RNA per bacterium. It is suggested that at the maximum induced rate of enzyme formation there are approximately $I I 0$ penicillinase messengers per bacterium, and in the constitutive about twice this number.
\end{abstract}

\section{INTRODUCTION}

The concept of unstable bacterial messenger RNA (m-RNA) is generally accepted and is implicated in the inducer-repressor enzyme control model as suggested by Jacob \& Monod (196I). While it is feasible that some structural proteins such as flagellin (see Martinez, 1966) might be exceptions, and that higher organisms may have relatively stable messengers (Revel \& Hiatt, I964; Gayler \& Glasziou, I968), it is not easy to accept, without strong evidence, that inducible bacterial enzymes have relatively stable messengers. Penicillinase is sometimes quoted as an example of inducible bacterial enzyme with a relatively stable messenger (for example, Forchhammer \& Kjeldgaard, 1967; Richmond, 1969) referring to the work of Pollock (1963) and Yudkin (1966). Yudkin (I966) reported that penicillinase messenger in the constitutive strain $749 / \mathrm{C}$ is more stable than in the inducible strain. Several other constitutive strains were later investigated (Yudkin, 1968) but similar results were not obtained, and quantitative measurement of messenger half-life was not presented.

In order to determine whether penicillinase is more stable than other bacterial messengers an attempt is made to estimate the half-life of in vivo messenger decay. An alternative explanation of high ('magno') levels of enzyme production is that more m-RNA is transcribed. A direct method for measuring intracellular levels of penicillinase m-RNA is not yet available, but some preliminary indirect estimations can be made. 


\section{METHODS}

Organisms. Bacillus licheniformis strain 749 inducible for penicillinase, and the constitutive mutant 749/C (see Pollock, 1963), were used in the experiments.

Growth conditions. Spores (see Collins, 1964) were germinated, and incubated for $12 \mathrm{hr}$, when the exponentially growing culture contained about $0.75 \mathrm{mg}$. dry weight organism $/ \mathrm{ml}$. A portion I $\mathrm{ml}$. of this seed culture was used to inoculate the experimental culture, in medium consisting of sodium L-glutamate ( $10 \mathrm{mg} . / \mathrm{ml}$.), casein hydrolysate (I mg. $/ \mathrm{ml}$.), maltose (0.25 mg. $/ \mathrm{ml}$.), thiamine (I $\mu \mathrm{g} . / \mathrm{ml}$.), $\mathrm{FeCl}_{2} .6 \mathrm{H}_{2} \mathrm{O}$ (0. I mg./ $\mathrm{ml}$.), $\mathrm{MnSO}_{4} \cdot \mathrm{H}_{2} \mathrm{O}(2 \mathrm{mg} . / \mathrm{ml}$.) and minimal basal salts ('MBS') consisting finally of $\left(\mathrm{NH}_{4}\right)_{2} \mathrm{SO}_{4}\left(2 \mathrm{mg} . / \mathrm{ml}\right.$.), $\mathrm{KH}_{2} \mathrm{PO}_{4}\left(5.5 \mathrm{mg} . / \mathrm{ml}\right.$.), $\mathrm{K}_{2} \mathrm{HPO}_{4}(\mathrm{I} 4.65 \mathrm{mg} . / \mathrm{ml}$.), sodium citrate $\left(3 \mathrm{mg} . / \mathrm{ml}\right.$.) and $\mathrm{MgSO}_{4} 7 \mathrm{H}_{2} \mathrm{O}(0.22 \mathrm{mg} . / \mathrm{ml}$.). Usually, $50 \mathrm{ml}$. cultures were incubated in $250 \mathrm{ml}$. conical flasks, aerated on a rotary shaker (at $280 \mathrm{revs} / \mathrm{min}$.) at $37^{\circ}$. Under these conditions, a doubling time of about $70 \mathrm{~min}$. was obtained. Growth was measured by optical density at $650 \mathrm{~nm}$ (O.D.650 (I cm. path) $\mathrm{I} \cdot 0 \equiv 0.3 \mathrm{mg}$. dry weight $/ \mathrm{ml} . \equiv 3 \times 10^{8}$ bacteria).

Induction. Strain 749 was induced with either I unit $(0.6 \mu \mathrm{g}$.) benzylpenicillin or I $\mu$ g. cephalosporin C (Glaxo Laboratories Ltd) / $\mathrm{ml}$. unless otherwise stated. Penicillinase synthesis was still being induced $60 \mathrm{~min}$. after addition of inducer, the maximum differential rate not being reached until after one doubling time after induction (Fig. I). In the experiments designed to determine messenger half-life, inducer was added 40 or $60 \mathrm{~min}$. before sampling or resuspending organisms. Bacteria for resuspension were collected by centrifugation at room temperature and resuspended in fresh warm medium, also containing the inducer; Io min. shaking was allowed before sampling. Growth continued at the same rate as before harvesting.

Sampling and enzyme assay. Samples $(2 \mathrm{ml}$.) were transferred at intervals of 2 or $5 \mathrm{~min}$. to tubes containing $0 . \mathrm{I} \mathrm{ml}$. ( $\mathrm{I} \mathrm{mg}$. $/ \mathrm{ml}$.) of chloramphenicol solution (Parke Davis and Co.), kept at $0^{\circ}$. Except when total enzyme was to be assayed, bacteria were pelleted and resuspended in $2 \mathrm{ml}$. of $10 \mathrm{~mm}$ potassium or sodium phosphate buffer, pH 6.9. Usually, these samples were frozen and thawed before assay. Triplicate portions were taken for penicillinase assay by the method of Perret (I954). One unit of enzyme is that amount of enzyme which hydrolyses I $\mu$ mole of benzylpenicillin in one hour at $\mathrm{pH} 7.0$ and $30^{\circ}$, with an enzyme-saturating concentration of substrate. One unit of enzyme is equivalent to $5.5 \times 10^{10}$ molecules (based on 440 units $/ \mu \mathrm{g}$. protein, the specific activity of purified $749 / \mathrm{C}$ exoenzyme: R. J. Meadway, personal communication).

Incorporation of amino acid and nucleotide. Samples from cultures containing ${ }^{14} \mathrm{C}-\mathrm{L}-$ phenylalanine for ${ }^{14} \mathrm{C}$-uracil were added direct to an equal volume of $20 \%(\mathrm{w} / \mathrm{v})$ trichloroacetic acid containing unlabelled phenylalanine or uracil accordingly. These suspensions were left overnight at $4^{\circ}$. Precipitates were collected on glass-fibre filters (Whatman GF/A), and washed with cold 10\% trichloroacetic acid containing uracil (I mg. $/ \mathrm{ml}$.), or hot $10 \%$ trichloroacetic acid containing phenylalanine (I $\mathrm{mg} . / \mathrm{ml}$.). The filters were subsequently washed with $95 \%(\mathrm{v} / \mathrm{v})$ ethanol containing $\mathrm{I} \%(\mathrm{w} / \mathrm{v})$ potassium acetate, absolute ethanol, ethanol + ether $(\mathrm{I}+\mathrm{I})$ and twice with ethyl ether. Dried filters were counted by liquid scintillation techniques (Davies \& Hall, I969).

Cell lysates and polysome preparations. Washed bacteria were resuspended in cold Io mM-tris- $\mathrm{HCl}(\mathrm{pH} \mathrm{7.8)}$ containing Io mM-magnesium acetate, $50 \mathrm{~mm}-\mathrm{KCl}$ and $5 \mathrm{~mm}$ dithiothreitol, and treated with lysozyme $\left(150-400 \mu \mathrm{g} . / \mathrm{ml}\right.$.) for $20 \mathrm{~min}$. at $10-15^{\circ}$, 
before cooling again in ice. Lysis was promoted by addition of the nonionic detergent Brij 58 (final concentration $0.25 \%$ ) and sodium deoxycholate (final concentration $0.02 \%$ ). Deoxyribonuclease (Sigma:ribonuclease free) $\mathrm{I}-3 \mu \mathrm{g} . / \mathrm{ml}$. was also added. Polysomes were obtained from this crude lysate by differential centrifugation (see Davies, 1969). Chloramphenicol (100 $\mu \mathrm{g} . / \mathrm{ml}$.) was added to cultures before harvesting, and to buffer solutions to prevent translation 'run off' of ribosomes from polysomes.

Sucrose gradient analysis. Lysozyme cell lysates or isolated polysome/ribosome preparations were analysed on linear $5 \%-20 \%$ sucrose gradients, containing $10 \mathrm{~mm}$ tris- $\mathrm{HCl}\left(\mathrm{pH} 7 \cdot 8 ; 5^{\circ}\right)$, Io mM-magnesium acetate, $50 \mathrm{~mm}-\mathrm{KCl}, 5 \mathrm{~mm}$-dithiothreitol and $0.02 \%(\mathrm{w} / \mathrm{v})$ sodium deoxycholate. Samples ( $\mathrm{I} \mathrm{ml}$.) were applied and centrifuged for $3 \frac{1}{2}-5 \mathrm{hr}$ at $30,000 \mathrm{revs} / \mathrm{min}$. in a $3 \times 23 \mathrm{ml}$. swing-out rotor (MSE superspeed 50 ). Fractions ( $\mathrm{I} \mathrm{ml}$.) were collected from the bottom of the tube through a hypodermic needle. Most gradients had a I ml. $20 \%$ sucrose 'cushion' at the bottom. Absorption at 260 or $280 \mathrm{~nm}$ was recorded for each fraction.

$R N A$ and protein determinations. RNA and protein were precipitated with cold $10 \%$ trichloroacetic acid. In some assays cell wall material was partially removed by lysozyme digestion. The precipitates were washed with ethanol and ethyl ether (see above) by centrifugation and resuspension. Washed precipitates were dissolved in O.I N$\mathrm{NaOH}$ at $60^{\circ}$. Samples in which the RNA was extracted with hot perchloric acid were also assayed. RNA was estimated by an orcinol method, based on that of Schneider (1957), using yeast total RNA as standard. Protein was assayed by the method of Lowry, Rosebrough, Farr \& Randall (I95I) using ovalbumin or bovine serum albumin as standards. Results given for RNA and protein per cell are mean values from several separate determinations.

\section{RESULTS}

Inhibition of growth by inhibitors of RNA synthesis

Concentrations of actinomycin D (Merck, Sharp and Dohme Ltd) and rifampicin (CIBA Laboratories Ltd) were required which would prevent synthesis of the majority of the proteins of the cell and therefore growth. Both antibiotics (I mg./ml.) rapidly inhibited exponential growth (Fig. 2), there being no multiplication for the next 10I 5 min. Some recovery of growth was then evident for a few minutes, resulting in slight stepwise growth. The critical period of m-RNA decay after inhibition of RNA synthesis occurred during the IO-1 $5 \mathrm{~min}$. when there was no growth.

\section{Inhibition of RNA synthesis, average cell messenger half-life, and total messenger content}

Both actinomycin D and rifampicin inhibited RNA synthesis almost immediately, as measured by incorporation of ${ }^{14} \mathrm{C}$ uracil into cold trichloroacetic acid-insoluble precipitates. The average cell messenger half-life was estimated from the kinetics of labelled RNA decay, and the bacterial content by the amount of rapidly decaying RNA compared with the concentration of stable RNA (Levinthal, Fan, Higa \& Zimmermann, 1963; Zimmermann \& Levinthal, 1967). Initially, decay kinetics were measured after pulse-labelling for I min but little difference in the decay rate was observed even after twenty minutes of labelling. The half-life was also calculated from 


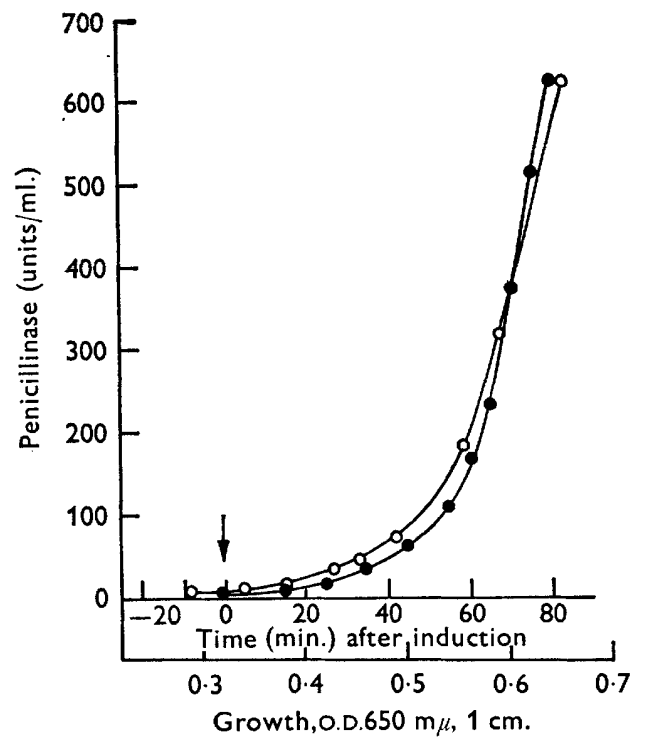

Fig. I

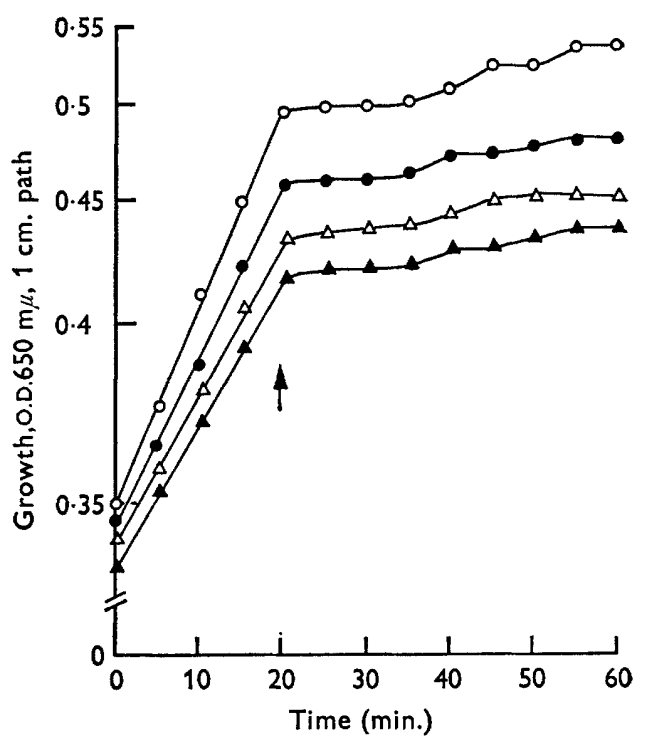

Fig. 2

Fig. I. Kinetics of induction and differential rate of synthesis of penicillinase by Bacillus licheniformis 749 . Inducer ( 5 units benzylpenicillin/ml.) was added when the culture had reached $0.1 \mathrm{mg}$ dry weight $/ \mathrm{ml}$. (doubling time $75 \mathrm{~min}$.). Total enzyme was assayed although most enzyme was cell-bound during this time. - shows kinetics of induction units of (enzyme/ $\mathrm{ml}$. vs. time after induction); $O$ differential rate of synthesis (units of enzyme/ml.vs. growth).

Fig. 2. Effect of actinomycin D and rifampicin on growth of Bacillus licheniformis 749. $O$ indicates $5 \mu \mathrm{g}$. actinomycin $\mathrm{D} / \mathrm{ml}$.; $\triangle$, I $\mu \mathrm{g}$. actinomycin $\mathrm{D} / \mathrm{ml}$.; $\odot 5 \mu \mathrm{g}$. rifampicin $/ \mathrm{ml}$.;

$\Delta$, I $\mu$ g. rifampicin $/ \mathrm{ml}$. The arrow indicates the time of addition.

the protein-synthesizing capacity, measured by ${ }^{14} \mathrm{C}$ amino acid incorporation. Both methods gave half-lives between 2 and $3 \mathrm{~min}$., averaging $2.5 \mathrm{~min}$. from eight determinations. Some results are given in Fig. 3. The m-RNA content, measured by the type of experiment shown in Fig. 3(a) but allowing two generations of labelling first, was estimated to be around 7-10\% of the cellular RNA. Slightly higher contents were apparent in rifampicin experiments (see Fig. $3(e)$ ).

\section{Penicillinase $m R N A$ half-life}

Enzyme-forming capacity after actinomycin $D$ treatment. The increase in induced penicillinase synthesis was measured after addition of actinomycin $D$ to exponentially growing cultures. Results were obtained for cephalosporin and benzylpenicillin induced organisms in fresh media and also without a medium change. Initially, bound, exoand total enzyme was measured (Fig. 4). 'Enzyme forming capacity' was calculated as the final (maximum) yield of enzyme minus the enzyme level at time $t$. Semi-log plots gave the half-life of the decay rate. Similar experiments were carried out with strain 749/C (Fig. 5). The estimated half-life was comparable to that for induced 749 (about $4.5 \mathrm{~min}$.). Occasionally, a decrease in enzyme activity was observed. This atypical phenomenon is not yet understood, but may involve a reversible inhibition of enzyme activity by actinomycin $\mathrm{D}$. In some experiments, therefore, the antibiotic was also added to the pre-20 min. samples such that all samples assayed contained the same concentration of actinomycin. 

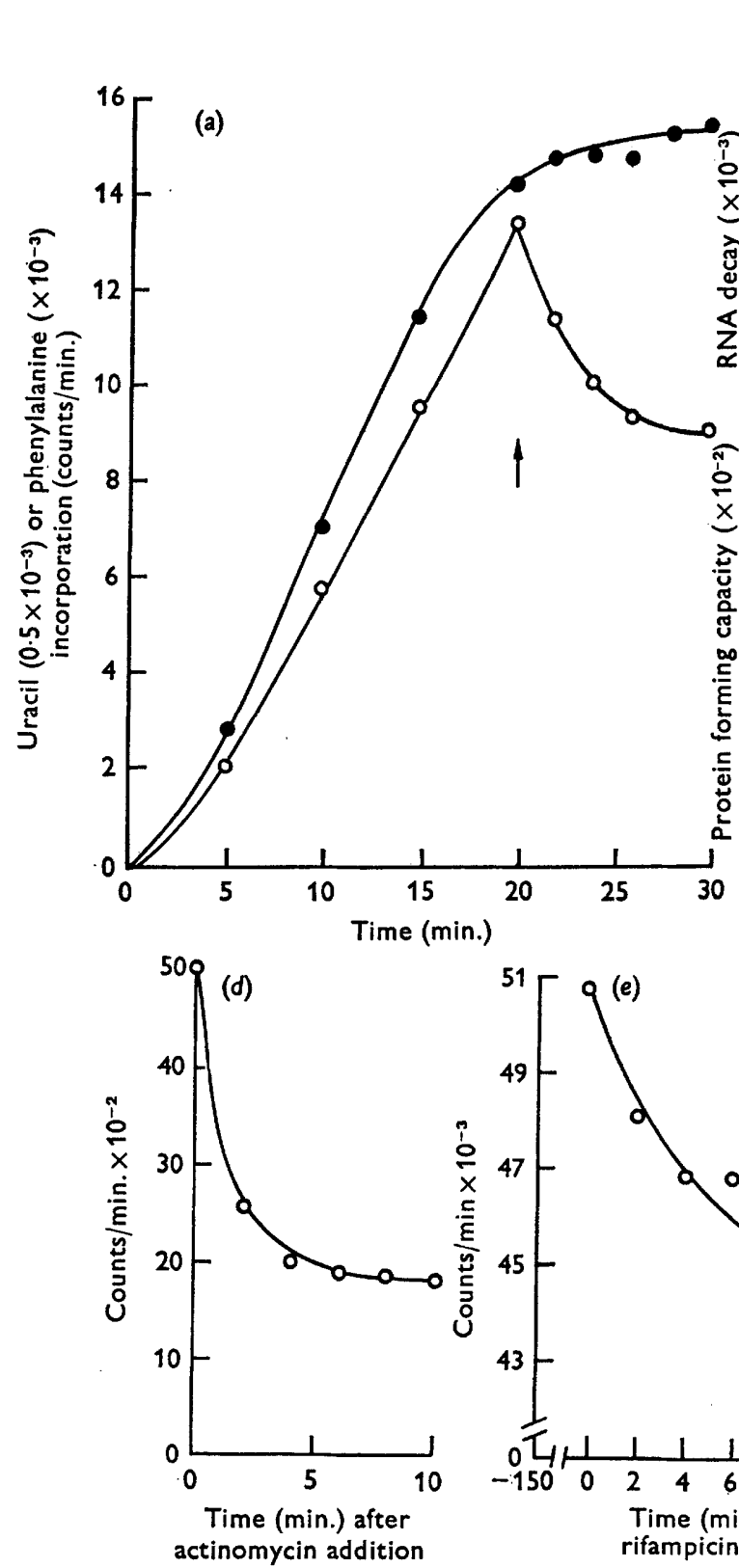

$80 g(b)$

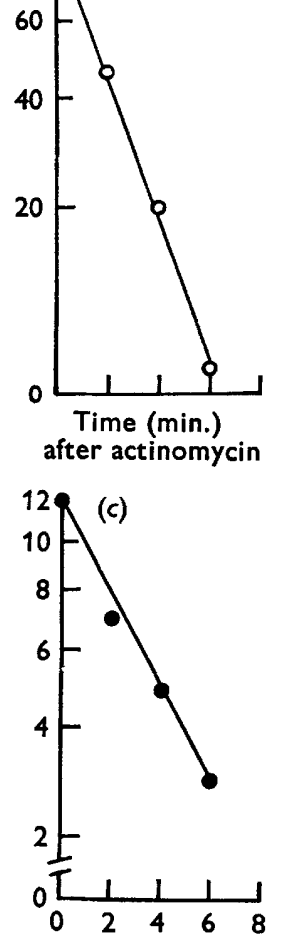

Time (min.)

after actinomycin

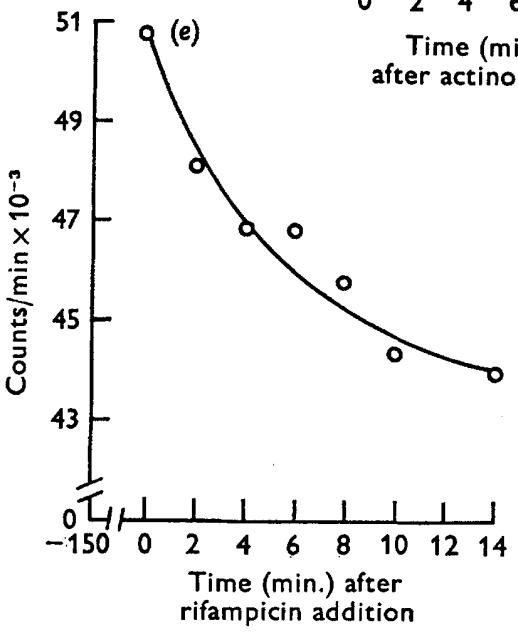

Fig. 3. Incorporation of ${ }^{14} \mathrm{C}$ uracil and ${ }^{14} \mathrm{C}$ phenylalanine into trichloroacetic acid-insoluble material during exponential growth, and the decay of total protein-forming capacity and unstable RNA in Bacillus licheniformis. ${ }^{14} \mathrm{C}$ Uracil $(50 \mu \mathrm{c} / \mu$ mole $)$ and ${ }^{14} \mathrm{C}$-L-phenylalanine $(25 \mu \mathrm{c} / \mu \mathrm{mole})$ were added to give $0.5 \mu \mathrm{c} / \mathrm{ml}$. (a). 1 indicates amino-acid incorporation ('total protein' synthesis); $\bigcirc$, uracil incorporation (RNA synthesis). Actinomycin (I $\mu \mathrm{g} . / \mathrm{ml}$.) added when indicated (arrow). (b) Semi-log plot of total m-RNA decay $\left({ }^{14} \mathrm{C}\right.$ uracil counts), calculated as counts/min. at time $t$ minus counts/min. finally. (c) Semi-log plot of total proteinforming capacity, calculated as counts/min. finally minus counts/min. at time $t$. $(d)$ and $(e)$ show decay of unstable RNA after long-period and short pulse labelling. In $(d)$ organisms were pulse-labelled with ${ }^{14} \mathrm{C}$ uracil for I min.; actinomycin $5 \mu \mathrm{g} . / \mathrm{ml}$. In $(e)$ cells were labelled for 2 generations $\left({ }^{14} \mathrm{C}\right.$ uracil I $\mu \mathrm{c}(5 \mu \mathrm{moles} / \mathrm{ml}$.) rifampicin $5 \mu \mathrm{g} . / \mathrm{ml}$.). Curve asymptote 4400 counts/min. 

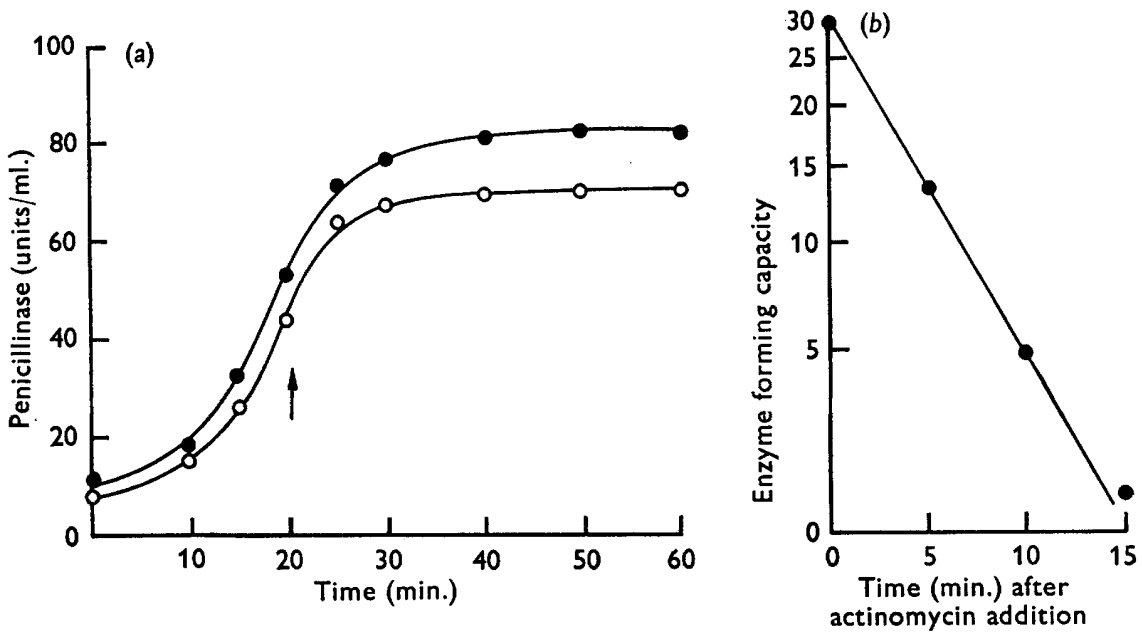

Fig. 4. Actinomycin inhibition of induced penicillinase synthesis, and decay of the enzymeforming capacity by Bacillus licheniformis 749. (a) Bacteria were not resuspended (optical density at $650 \mathrm{~nm}$ at zero time $=0.15$ ), but were induced with I $\mu \mathrm{g}$. cephalosporin $/ \mathrm{ml}$. $35 \mathrm{~min}$. before assaying. Actinomycin D I $\mu \mathrm{g}$. $/ \mathrm{ml}$. finally (arrow). $\bullet$, indicates total enzyme; $O$, cell-bound enzyme. The arrow indicates the time of addition of actinomycin $D$ to give a final concentration of $\mathrm{I} \mu \mathrm{g} . / \mathrm{ml}$. (b) Semi-log plot of enzyme-forming capacity after addition of actinomycin. Similar results were obtained for penicillin-induced cells resuspended in fresh medium.

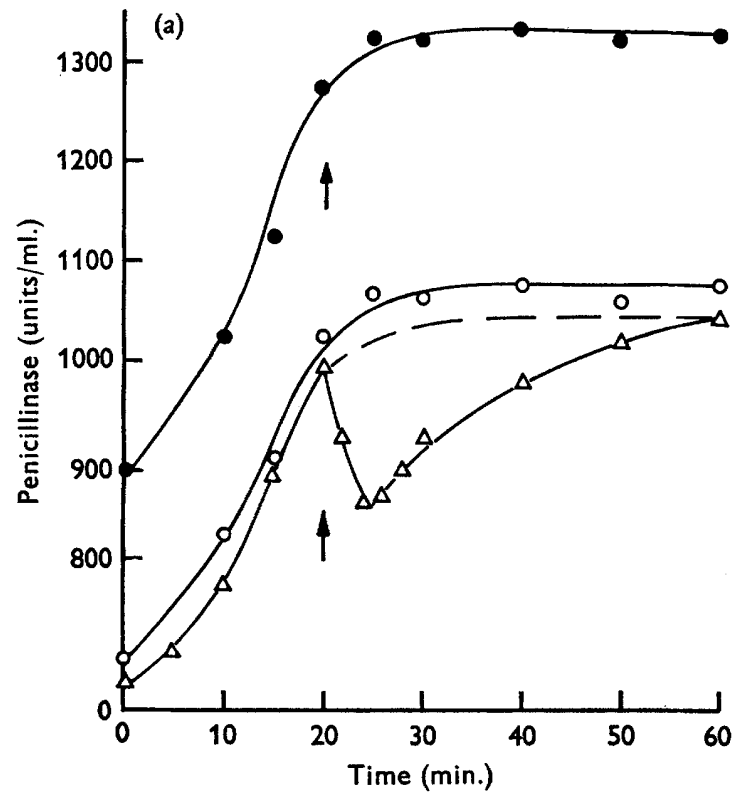

(b)

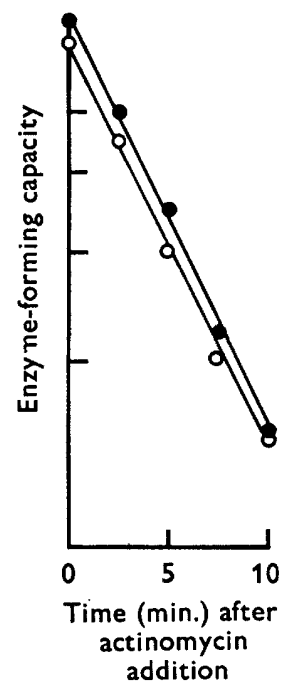

Fig. 5. Actinomycin inhibition of constitutive penicillinase formation, and the decay of enzyme forming capacity by Bacillus licheniformis $749 / \mathrm{c}$. Bacteria were resuspended in fresh medium Io min. before the zero-time sample (optical density at $650 \mathrm{~nm}=\mathrm{I} \cdot 0$ ). $(a)$ total enzyme; $O$ cell bound enzyme. The arrow indicates the time of addition of actinomycin $\mathrm{D}$, to give a final concentration of $\mathrm{I} \mu \mathrm{g} . / \mathrm{ml} . \Delta$, indicates an atypical effect obtained in a separate experiment in which maltose was omitted and actinomycin was added to give a final concentration of $5 \mu \mathrm{g} . / \mathrm{ml}$. (b) Semi-log plots of enzyme-forming capacity. 
Enzyme-forming capacity after rifampicin treatment. In view of the possibility that actinomycin D may have a preferential effect on some cistrons, or that it could influence messenger decay, experiments were performed with rifampicin, which inhibits
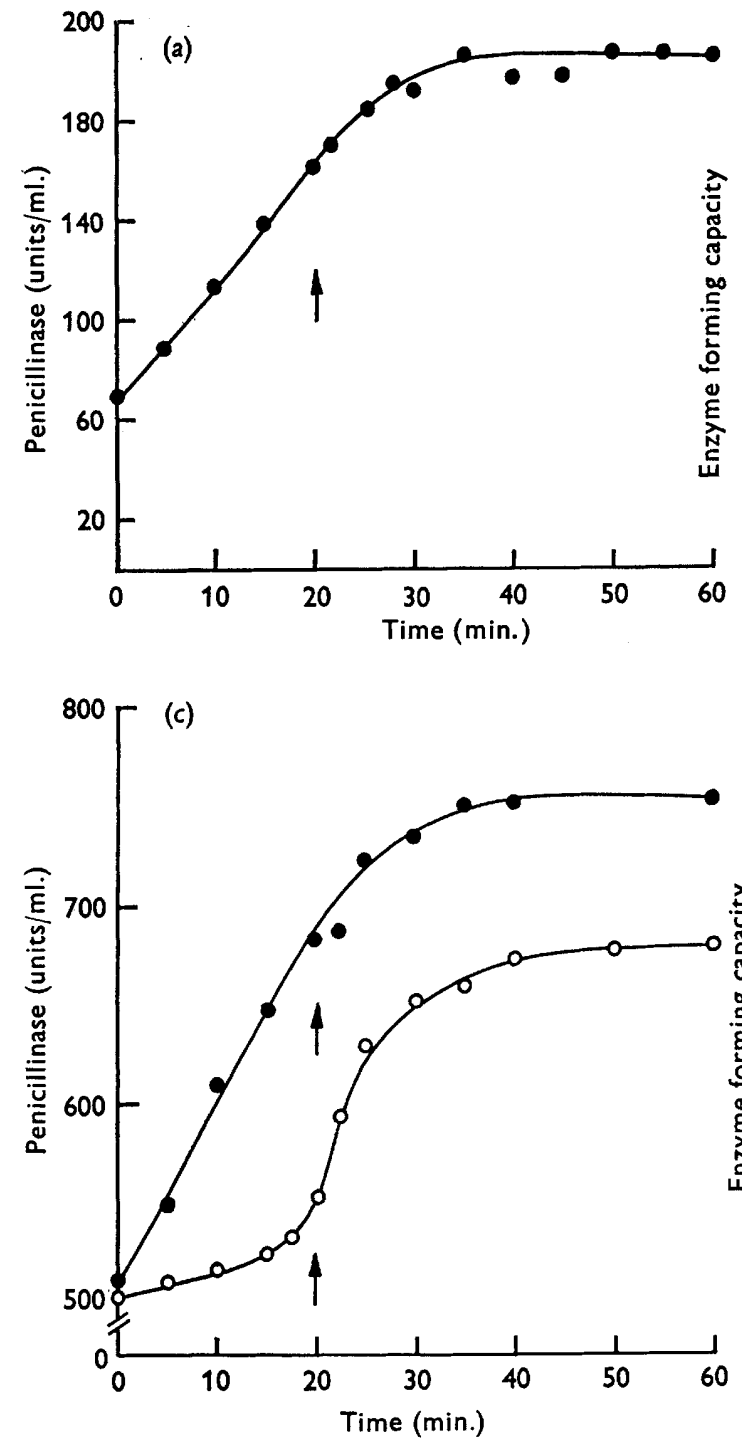

(b)

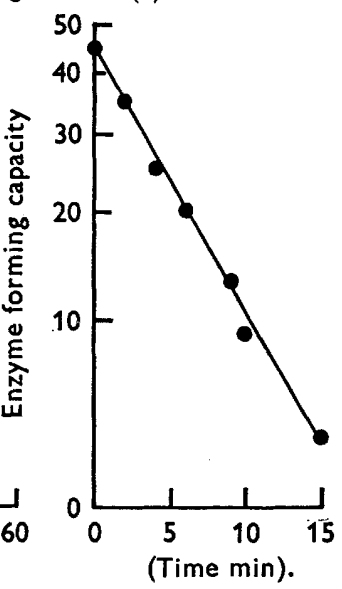

(d)

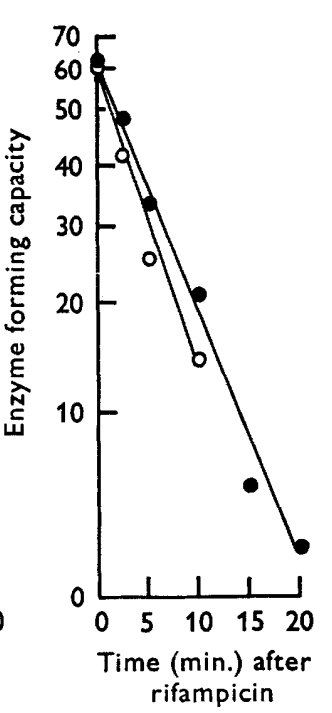

Fig. 6. Rifampicin inhibition of induced and constitutive penicillinase formation by Bacillus licheniformis, and decay of the enzyme-forming capacity. (a) Strain 749, induced with I $\mu \mathrm{g}$. cephalosporin $/ \mathrm{ml}$. $60 \mathrm{~min}$. before resuspending in fresh medium zero time Io min. before. Optical density at $650 \mathrm{~nm}=0.15$. The arrow indicates the time of addition of rifampicin to give a final concentration of I $\mu \mathrm{g}$. $/ \mathrm{ml}$. (b) Semi-log plot of enzyme-forming capacity by strain 749. (c) Strain $749 / \mathrm{c}$. The initial optical density at $650 \mathrm{~nm}=0.4$. indicates sampling started immediately (not resuspended); $O$, cells resuspended in fresh medium. Results are for cell-bound enzyme only. Rifampicin I $\mu \mathrm{g}$. $/ \mathrm{ml}$. (d) Semi-log plot of enzyme forming capacity by strain $749 / \mathrm{c}$. 
action of RNA polymerase, thus stopping transcription generally. The kinetics of enzyme-forming capacity after rifampicin addition suggested messenger decay with a half-life around 4-5 min., both for the inducible and constitutive strains (Fig. 6). Results of actinomycin and rifampicin experiments are summarized in Table $\mathrm{I}$.

\section{Cell contents of RNA, protein and penicillinase}

Cell contents of protein and RNA were estimated, and the average cell content during exponential growth was calculated (Table 2). The level of penicillinase was also estimated from a large number of determinations, made at least 80-120 min. after induction, when the bacteria were close to or at the maximum differential rate of synthesis. It is emphasised that these results are a population average during exponential growth only. The figure of 107,000 molecules of penicillinase is the average cell content and corresponds to 2340 units of enzyme per mg. dry weight of organism. The amount of penicillinase to be synthesized by a single bacterium per division cycle, is in $2 \times$ average

\section{Table I. Stability of penicillinase messenger RNA in Bacillus licheniformis}

Penicillinase messenger half-life was estimated from semi-log plots of the enzyme-forming capacity, from several experiments of the type shown in Fig. 4, 5 and 6

\begin{tabular}{|c|c|c|c|c|}
\hline \multirow[b]{2}{*}{$\begin{array}{l}\text { Inhibitor of } \\
\text { RNA synthesis }\end{array}$} & \multicolumn{2}{|c|}{ Strain 749} & \multicolumn{2}{|c|}{ Strain $749 / \mathrm{c}$} \\
\hline & $\begin{array}{c}\text { Mean } \\
\text { half-life (min.) }\end{array}$ & $\begin{array}{c}\text { No. of } \\
\text { determinations }\end{array}$ & $\begin{array}{c}\text { Mean } \\
\text { half-life (min.) }\end{array}$ & $\begin{array}{c}\text { No. of } \\
\text { determinations }\end{array}$ \\
\hline $\begin{array}{l}\text { Actinomycin D } \\
\text { (I } \mu \mathrm{g} . / \mathrm{ml} \text { ) }\end{array}$ & $5 \cdot 0 \pm I \cdot 0$ & 4 & $4.2 \pm 0.25$ & 2 \\
\hline $\begin{array}{l}\text { Actinomycin D } \\
(2 \mu \mathrm{g} . / \mathrm{ml} .)\end{array}$ & - & - & $4 \cdot 0 \pm 0$ & 2 \\
\hline $\begin{array}{l}\text { Actinomycin D } \\
(5 \mu \mathrm{g} . / \mathrm{ml} .)\end{array}$ & $5 \cdot 0 \pm 0$ & I & $5 \cdot 0 \pm 0$ & I \\
\hline $\begin{array}{l}\text { Rifampicin } \\
\text { (I } \mu \mathrm{g} . / \mathrm{ml} .)\end{array}$ & $4.5 \pm 0.5$ & 2 & $5.9 \pm 0.5$ & 5 \\
\hline $\begin{array}{l}\text { Rifampicin } \\
(5 \mu \mathrm{g} . / \mathrm{ml} .)\end{array}$ & $4.4 \pm 0.4$ & 2 & $4 \cdot 0 \pm I \cdot 0$ & 2 \\
\hline Mean half-life* & $4 \cdot 7$ & - & $4 \cdot 7$ & - \\
\hline
\end{tabular}

* The mean half-life was calculated from an equal number of determinations for each concentration of the inhibitors.

Table 2. Cell content of total protein, $R N A$, unstable $R N A$ and penicillinase in Bacillus licheniformis

$\quad$ Component
Protein (total)
RNA (total)
m-RNA*
Penicillinase $\dagger$
(molecules/generation)

Average cell content

$$
\begin{aligned}
& 6 \cdot 5( \pm \mathrm{I} \cdot 0) \times 10^{-7} \mu \mathrm{g} . \\
& \mathrm{I} \cdot 5( \pm 0.5) \times 10^{-7} \mu \mathrm{g} . \\
& 0 \cdot 12( \pm 0.04) \times 10^{-7} \mu \mathrm{g} . \\
& 107,000 \pm 16,000
\end{aligned}
$$

$\%$ of dry weight of bacterium

$$
\begin{gathered}
55-75 \\
10-20 \\
0.2-1 \cdot 6 \\
0.44-0.60
\end{gathered}
$$

Bacillus licheniformis 749 was induced with I $\mu \mathrm{g} . / \mathrm{ml}$. (approx. I unit $/ \mathrm{ml}$.) cephalosporin C. Similar values, within the variation range shown, are obtained for cultures induced with up to $5 \mu \mathrm{g}$. cephalosporin $\mathrm{C}$ or penicillin $/ \mathrm{ml}$. Growth conditions and medium as described in Methods. Generation time (doubling time) varied from 65 to $75 \mathrm{~min}$.

* m-RNA is assumed to be that which is rapidly labelled, and which decays quickly after addition of actinomycin D. Total average contents are calculated from experiments of the type shown in Fig. 3.

$\dagger$ Total enzyme: strictly speaking not 'cell content' since about $20 \%$ is released as exoenzyme. 
cell content of penicillinase $(107,000 \times 0.693=74,150 \mathrm{molecules} /$ bacteria/division cycle). The constitutive strain $(749 / \mathrm{c})$ produced about twice that amount of enzyme under the same conditions.

\section{Number of nascent polypeptide chains per bacterium}

The average number of nascent chains per bacterium (equivalent to the numbers of ribosomes synthesizing penicillinase) can be calculated directly from the number of molecules synthesized per bacterium per generation, if the rate of peptide bond synthesis is known (J. Imsande, personal communication):

nascent chains $/$ bacterium $=\frac{\text { molecules } / \text { bacterium } / \text { division cycle } \times \text { amino acids } / \text { molecule }}{\text { generation time }(\mathrm{sec} .) \times \text { peptide bond rate }}$

Kepes \& Beguin (1966) suggest an average 'step time' for peptide bond formation of $65 \mathrm{msec}$. at $37^{\circ}$. This corresponds to a rate of $15-16$ amino acids/sec., the rate quoted by Maaløe \&Kjeldgaard ( 1966 ) for Escherichia coli growing at a rate of I-2 generations/ hour at $37^{\circ}$. This figure is assumed for $B$. licheniformis. Exopenicillinase has 265 amino acids/molecule (Ambler \& Meadway, 1969); the newly synthesized cell-bound enzyme is assumed in this work to have 270 amino acids (it is thought that during release of the enzyme, some terminal amino acids are removed). Thus, if 74,I50 molecules are synthesized in a generation time of $70 \mathrm{~min}$., at a rate of 16 amino acids $/ \mathrm{sec}$. and 270 amino acids/molecule, then there are about 300 nascent chains of penicillinase per bacterium when induced to the maximum rate of synthesis. The constitutive strain has about 700 nascent chains per bacterium.

\section{Penicillinase polysome size}

Attempts were made to measure the size of the penicillinase polysome on sucrose gradients. That the enzyme activity peaks in the polysome region mainly represented nascent chains, rather than free enzyme absorbed or otherwise associated with other ribosomes, was suggested by the following evidence. Polysome-ribosome preparations incubated in vitro (see Davies, I969) showed penicillinase activity associated with the labelled polysome region, and not associated or bound to inactive monosomes, although these were in excess (Fig. 7a). A separate peak was identified in the polysome region for non-induced bacteria, high levels of enzyme which might obscure the true picture being absent (Fig. 7c). Uracil pulse-labelling and electron microscopy were used to ascertain that the fractions were polysomes. Experiments were also carried out only $60 \mathrm{~min}$. after induction, when the enzyme was not released as free exoenzyme and could not therefore absorb onto ribosomes. The majority of cell-bound enzyme is associated with particles of large molecular weight (see Lampen, I967; Davies, 1969) thought to be bacterial membrane, and therefore probably not free to absorb easily onto ribosomes. Penicillinase released from these washed polysome preparations was found to be about the same size and charge as the main exoenzyme fraction. Penicillinase peaks were routinely identified, and corresponded to a polysome size of 2-3 ribosomes (estimated from distance moved from the meniscus relative to $70 \mathrm{~s}$ ribosomes; see Martin \& Ames, 196I). Some results are shown in Fig. 7. Polysome sizes ranging from 2 to 5 ribosomes were obtained, but mostly a size of 2 to 3 ribosomes was indicated. The figure of 3 ribosomes per message (for a doubling time of $70 \mathrm{~min}$.) was assumed for further calculations. 

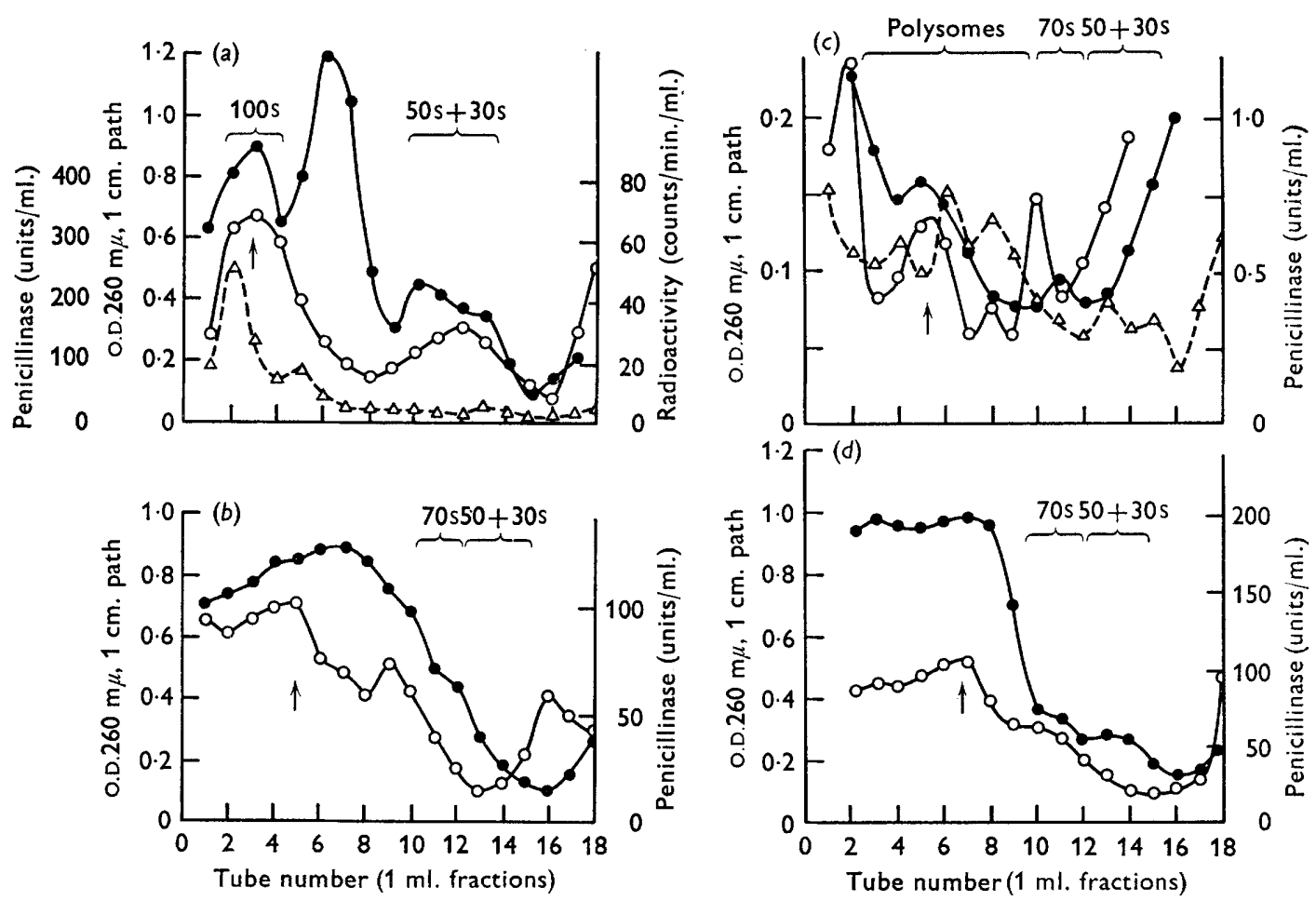

Fig. 7. Sucrose-gradient analysis of cell lysates and polysome preparations from Bacillus licheniformis. (a) Analysis of polysomes from strain $749 / \mathrm{C}$ incubated for $20 \mathrm{~min}$. under cellfree protein synthesizing conditions (Davies, I969) to incorporate ${ }^{14} \mathrm{C}$-L-leucine into nascent polypeptide chains. Re-isolated polysomes and ribosomes were then centrifuged for $5 \mathrm{hr}$ on a sucrose gradient. Penicillinase (arrow) and radioactivity are associated with polysomes (IOO S), not with the large 70-80 s monosome peak. indicates optical density $280 \mathrm{~nm}$; $O$, penicillinase activity; $\triangle$, radioactivity. (b) Polysomes isolated from strain $749 / \mathrm{c}$ pretreated with chloramphenicol (IOO $\mu \mathrm{g} . / \mathrm{ml}$.): note absence of the $70 \mathrm{~s}$ peak. Bacteria were grown in nutrient broth (doubling time approximately $60 \mathrm{~min}$.). Gradient was centrifuged for $3 \mathrm{hr}$. $\bigcirc$ indicates optical density $280 \mathrm{~nm}$.; $\bigcirc$, penicillinase activity. The main penicillinase peak around tubes 4 and 5 (arrow) corresponds to a polysome of about 3-5 ribosomes. The smaller peak, corresponding to about $80-100 \mathrm{~s}$ is thought to be due to 'monomers' and 'dimers' from breakdown of the larger polysomes. (c) Crude lysates from strain 749 noninduced. Doubling time was $70 \mathrm{~min}$. Approximately $90 \%$ lysis was obtained. Tubes I-2 contained some cells and cell-wall debris. A 40-sec. pulse of ${ }^{14} \mathrm{C}$ uracil was given immediately before harvesting. Gradient was centrifuged for $3.5 \mathrm{hr}$. A large proportion of the uracil label, representing $\mathrm{m}$-RNA, was in the polysome region. The penicillinase peak in the polysome region (arrow) corresponds to 3 to 4 ribosomes. Penicillinase activity (basal) was assayed by the Pardee assay (see Imsande \& Gerber, 1967). $\triangle$ indicates radioactivity; $\bigcirc$, penicillinase activity; O, optical density at $260 \mathrm{~nm}$. (d) Isolated polysomes from strain 749 induced for $60 \mathrm{~min}$. and chloramphenicol treated. Doubling time was $75 \mathrm{~min}$. Gradient centrifuged for $3.5 \mathrm{hr}$. The suggested penicillinase polysome position (see Fig. $7 \mathrm{c}$ ) corresponding to 2-3 ribosomes is indicated. indicates optical density at $260 \mathrm{~nm}$.; 0 , penicillinase activity. Polysome sizes were calculated from $d_{1} / d_{2}=\left(N_{1} / N_{2}\right)^{\frac{2}{2}}$ where $d$ is the distance moved (approximated by tube number) and $N$ is the number of ribosomes. Calculations were relative to $N_{1}=$ I for $70 \mathrm{~s}$ ribosomes (for theory and discussion, see Martin \& Ames, 196I). 


\section{Cell content of penicillinase messenger}

Three approaches have been taken to estimate the average cell content of penicillinase messenger RNA.

From the numbers of nascent chains and polysome size. The number of nascent chains per bacterium must be:

polysome size (ribosomes/message) $\times$ messages/bacterium.

Thus, under the growth conditions used in these experiments when the number of nascent chains per bacterium is about 300 for induced strain 749 , the numbers of messages per bacterium would be I00, taking a polysome size of 3 ribosomes/message. The polysome size in the constitutive is the same as in the inducible but the number of nascent chains is higher, thus the number of messages is also higher (230).

From messenger stability. The cell content of penicillinase messenger can be estimated from the average life-time $(T)$ of the molecules, and the amount of enzyme made in a generation. If $t \frac{1}{2}$ is the half-life of a population of molecules, then since $T=\mathrm{I} / \lambda$ where $\lambda$ is the decay constant, then $T=I \cdot 443 t \frac{1}{2}$. Thus, the half-life of $4.7 \mathrm{~min}$. (Table I) corresponds to an average life-time for individual molecules of $6.78 \mathrm{~min}$. The rate of synthesis of penicillinase is about 3.5 molecules per ribosome per minute (equivalent to 270 amino acids polymerized at 16 amino acids $/ \mathrm{sec}$.). The number of times a messenger is $\mathrm{read}$ (protein molecules made per message) $=$ messenger life $\times$ ribosomes/ message $\times$ rate of synthesis, giving a value of $71(6.78 \times 3.0 \times 3.5)$. This, divided into the number of enzyme molecules made by a single bacterium in a generation $(74,150)$ gives the number of messages used in a generation. For a $70 \mathrm{~min}$. generation time, this is I059. If the messenger life time is $6.64 \mathrm{~min}$., then at any one time there are $1059 \times$ $6 \cdot 64 / 70=100$ penicillinase messenger molecules/cell.

From the level of penicillinase protein and total messenger RNA per bacterium. Since one unit of enzyme is equivalent to $2 \cdot 27 \times 10^{-3} \mu \mathrm{g}$. of protein, the specific activity of 2340 units $/ \mathrm{mg}$. dry weight is equivalent to $5 \cdot 3 \mu \mathrm{g}$. of penicillinase protein $/ \mathrm{mg}$. dry weight. However, the average total protein content is about $65 \%$ of the dry weight (Table 2) or $650 \mu \mathrm{g}$. total protein $/ \mathrm{mg}$. dry weight. Thus penicillinase is equivalent to $0.8 \%$ of the total protein (in $749 / \mathrm{C}, \mathrm{r} \cdot 6-2 \%$ ). The average total messenger RNA content is $\mathrm{I} \cdot 2 \%$ of the dry weight (Table 2 ).

Thus, if this quantity of messenger is responsible for the total cell protein, then $0.0096 \%$ (m-RNA $\%$ of dry weight) would be required to make $0.8 \%$ of the total protein. Penicillinase messenger could therefore account for $0.0096 \%$ dry weight, or $0.96 \times 10^{-10} \mu \mathrm{g}$. (dry weight of one bacterium approximately $10^{-6} \mu \mathrm{g}$.; I mg. $\equiv \mathrm{IO}^{9}$ bacteria). Penicillinase m-RNA is assumed to have 810 nucleotides (triplets for 270 amino acids). From the genetic code and amino-acid composition of penicillinase, an approximation of the likely GC content of the messenger can be made; this is estimated to be $50 \%$, which indeed might be expected as an 'average' composition. Thus, with equal amounts of the four bases, an average nucleotide molecular weight (340) can be used to estimate the molecular weight of penicillinase messenger as $340 \times 810=275,400$. The level of $0.96 \times 10^{-10} \mu \mathrm{g}$. penicillinase m-RNA $=6.03 \times 10^{23} \times 0.96 \times 10^{-10} / 2.75 \times$ $\mathrm{IO}^{5} \times \mathrm{IO}^{6}=2 \mathrm{IO}$ molecules/induced bacterium. This figure represents the average number of penicillinase messengers per bacterium in the exponential growing population. The number of messengers a single bacterium synthesizes during its division cycle is 
$2 \mathrm{IO} \times \ln 2$, which is 145 . Taking into account the errors indicated in Table 2, there is an overall error in this figure of about $\pm 40 \%$. A figure of 145 penicillinase messenger molecules/bacterium agrees closely with the values calculated by the first two methods, the overall average being approximately i Io penicillinase messages/bacterium for induced 749 , and approximately twice this number for the constitutive strain.

\section{DISCUSSION}

Recent work has provided good arguments for the reliability of the techniques used in this work. First the results of Fan (I966) indicate that, after repression of m-RNA synthesis, subsequent formation of enzymes is largely due to translation of intact messengers, not completion of partially translated messengers. Second, although Acs, Reich \& Valanju (1963) suggested that actinomycin D caused some breakdown of RNA, it is now considered that this effect is negligible (see Leive, 1965; Salser, Janin \& Levinthal, I968). Results for enzyme messenger stability using actinomycin D (Hartwell \& Magasanik, 1963, 1964; Leive \& Kollin, 1967) are comparable to results obtained by inducer removal (see Kepes, I963; Nakada \& Magasanik, 1964). Third, an independent technique involving the effects of turnover rate and quantity of unstable RNA on the labelling kinetics of the GTP pool has been developed (Salser et al. I968), which gives results comparable with those observed for actinomycin experiments.

Rifampicin, unlike actinomycin, binds to RNA polymerase (Wehrli, Knüsel, Schmid \& Staehelin, 1968), and only to polymerase free from the transcription complex (see von Hartmann, Behr, Beissner, Honikel \& Sippel, 1968). For messengers of average size around I000 bases, like penicillinase, transcription takes $20-30 \mathrm{sec}$. During this time, rifampicin may not exert its full effect, but this does not alter the decay rate significantly. The gene for a very large protein, or more so, a polycistronic messenger, may have several or many RNA polymerase molecules transcribing at once. Thus, after addition of rifampicin, a considerable number of intact messengers can be formed. For penicillinase, however, the rifampicin results confirmed those obtained with actinomycin (Table I).

The value for the penicillinase messenger RNA half-life of $4.7 \mathrm{~min}$. seems contradictory to previous reports (Pollock, I963; Yudkin, 1966, I968). However, several points should be taken into consideration. Firstly, messenger decay is a function of the rate of translation and can be protected by lower temperatures or decreased aeration conditions (Levinthal et al. 1963). The rapid rotary shaking used in the experiments reported here may afford higher aeration compared to the conditions employed by Yudkin, who also performed experiments at $30^{\circ}$ and $25^{\circ}$, not $37^{\circ}$. Secondly, samples taken at, say, ro min. intervals miss the early kinetics, and show results for recovered growing cells (see Fig. 2). If bacteria are still growing (as in the experiments of Pollock, I963), the proteins required for growth are being synthesized; thus continued synthesis of penicillinase need not imply a messenger any more stable than that of the average cell protein.

A short-lived penicillinase messenger $\left(t \frac{1}{2}=2 \mathrm{~min}\right.$.) has been suggested by similar actinomycin and rifampicin experiments with Bacillus cereus 569 (J. Imsande and J. W. Davies, unpublished results).

Two of the approaches taken to estimate contents of penicillinase m-RNA in bacteria involved the polysome size. A recent model for tryp m-RNA translation in 
Escherichia coli at $37^{\circ}$ is that ribosomes occupy $20-40 \%$ of the outstretched tryp polycistronic messenger (Morse, Baker \& Yanofsky, 1968). For the penicillinase messenger of only $5000 \AA$, 5 ribosomes per message $(20 \%$, assuming that one ribosome occupied $200 \AA$ ) would still be consistent with the model. Zimmermann \& Levinthal (1967) calculate that, in Bacillus subtilis (in which unstable RNA accounts for $8 \%$ of the total RNA), there may be about 500 nucleotides of m-RNA per 70 s ribosome. On this reckoning, penicillinase messenger would be expected to have about 2 ribosomes. The size of 3 ribosomes per message used in the calculations of contents of penicillinase messenger in bacteria is therefore thought to be of the right order, but with a possible error of about $\pm 60 \%$. Thus, the estimation of the content of penicillinase messenger in bacteria also cannot be expected to be better than $\pm 60 \%$ on overall average. That all the data used in the three approaches to estimate messenger content including the messenger half-life can be integrated and show consistency, is to some extent a test of the validity of the figures.

The technique of hybridization of specific bacteriophage RNA may afford a more direct approach, although assumptions concerning the specific activity and percentage of hybridization are necessary. Using that technique, Stubbs \& Hall (I968) estimate that wild-type Escherichia coli has about 2 tryp m-RNA molecules per bacterium, while a constitutive mutant has 25. Edlin, Stent, Baker \& Yanofsky (1968) estimate 4-8 tryp m-RNA molecules per bacterium (corrected values) when fully derepressed. It seems likely that the levels of penicillinase messenger in non-induced and constitutive bacteria also vary, rather than stabilization of the messenger (Harris \& Sabath, 1964; Yudkin, 1966) accounting for higher levels of enzyme.

I wish to thank Dr J. Imsande for the idea on the calculation of nascent chains, and other suggestions; also with Professor M. R. Pollock, Dr W. J. Brammar and Dr J. F. Collins for commenting on the manuscript. Thanks are also given to Miss S. Fleming for reliable technical assistance. This work was supported by a Medical Research Council grant (901/070) to the research group on Bacterial Enzyme Variation.

\section{REFERENCES}

ACS, G., Reich, E. \& VAlANJU, S. (I963). RNA metabolism of B. subtilis: effects of actinomycin. Biochim. biophys. Acta 76, 68.

Ambler, R. P. \& Meadway, R. J. (1969). Chemical structure of bacterial penicillinases. Nature, Lond. 22,2, 24.

Coluns, J. F. (1964). The distribution and formation of penicillinase in a bacterial population of Bacillus licheniformis. J. gen. Microbiol. 34, 363.

Davies, J. W. (1969). Protein synthesis by cell-free extracts from Bacillus licheniformis. Biochim. biophys. Acta 174, 686.

DAVIES, J. W. \& HALL, T. C. (1969). Liquid scintillation counting methods for accurate assay of beta radioactivity in biological experiments. Analyt. Biochem. 27, 77.

EdLin, G., Stent, G. S., BAKer, R. F. \& YANOFSKY, C. (1968). Synthesis of a specific messenger RNA during amino acid starvation of Escherichia coli. J. molec. Biol. 37, 257.

FAN, D. P. (1966). Decay of intact messengers in bacteria. J. molec. Biol. 16, 164.

ForCHHAMMER, J. \& KJELDGAARD, N. O. (1967). Decay of messenger RNA in vivo in a mutant of Escherichia coli 15. J. molec. Biol. 24, 459.

Gayler, K. R. \& Glasziou, K. T. (I968). Plant enzyme synthesis: decay of messenger RNA for peroxidase in sugar-cane stem tissue. Phytochemistry 7, 1247.

HarRIs, H. \& Sabath, L. D. (1964). Induced enzyme synthesis in the absence of concomitant RNA synthesis. Nature, Lond. 202, 1078. 
Hartmann, G. von, Behr, W., Beissner, K., Honikel, K., Sippel, A. (1968). Antibiotica als Hemmstoffe der Nucleinsäure und Proteinsynthese. Angew. Chem. 80, 710.

Hartwell, L. H. \& Magasanik, B. (1963). The molecular basis of histidase induction in Bacillus subtilis. J. molec. Biol. 7, $40 \mathrm{I}$.

Hartwell, L. H. \& Magasanik, B. (I964). The mechanism of histidase induction and formation in Bacillus subtilis. J. molec. Biol. I0, 105.

IMSANDE, J. \& GeRBER, M. J. (1967). Induction of pencillinase with inorganic phosphate. J. Bact. 94, 1672 .

JACOB, F. \& MoNOD, J. (I96I). Genetic regulatory mechanisms in the synthesis of proteins. J. molec. Biol. 3, 3 I 8 .

KePES, A. (1963). Kinetics of induced enzyme synthesis. Determination of the mean life of galactosidase-specific messenger RNA. Biochim. biophys. Acta 76, 293.

KePeS, A. \& Beguin, S. (1966). Peptide chain initiation and growth in the synthesis of $\beta$-galactosidase. Biochim. biophys. Acta $\mathbf{2 3}, 546$.

LAMPEN, J. O. (1967). Cell bound penicillinase of B. licheniformis; properties and purification. J. gen. Microbiol. 48, 249.

LEIVE, L. (1965). RNA degradation and the assembly of ribosomes in actinomycin-treated Escherichia coli. J. molec. Biol. r3, 862.

LeIve, L. \& Kollin, V. (1967). Synthesis, utilization and degradation of lactose operon mRNA in Escherichia coli. J. molec. Biol. 24, 247.

Levinthal, C., Fan, D. P., Higa, A. \& Zimmerman, R. A. (i963). The decay and protection of messenger RNA in bacteria. Cold Spr. Harb. Symp. quant. Biol. 28, 183.

Lowry, O. H., Rosebrough, N. J., FARr, A. L. \& Randall, R. J. (I95I). Protein measurement with the Folin pheno lreagent. J. biol. Chem. 193, 265.

MaAløe, O. \& KJeldgaARd, N. O. (1966). Control of Macromolecular Synthesis. New York and Amsterdam: W. A. Benjamin, Inc.

MARTIN, R. G. \& AMES, B. N. (I96I). A method for determining the sedimentation behaviour of enzymes: application to protein mixtures. J. biol. Chem. 236, I372.

MARTinez, R. J. (I966). The formation of bacterial flagella. II. The relative stability of messenger RNA for flagellin biosynthesis. J. molec. Biol. 17, 10.

Morse, D. E., BaKer, R. F. \& YANOFSKy, C. (I968). Translation of the tryp mRNA of E. coli. Proc. natn. Acad. Sci. U.S.A. 60, 1428.

NAKADA, D. \& MagasaniK, B. (1964). The roles of inducer and catabolite repressor in the synthesis of $\beta$-galactosidase by Escherichia coli. J. molec. Biol. 8, 105.

Perret, C. J. (1954). Iodometric assay of penicillinase. Nature, Lond. 174, IOI 2.

Pollock, M. R. (1963). The differential effect of actinomycin D on the biosynthesis of enzymes in Bacillus subtilis and Bacillus cereus. Biochim. biophys. Acta 76. 80.

Revel, M. \& Hiatt, H. H. (1964). The stability of liver messenger RNA. Proc. natn. Acad. Sci., U.S.A. 46, 1044 .

RICHMOND, M. H. (1969). Enzymic adaptation in bacteria: its biochemical and genetic basis. In Essays in Biochemistry, ed. by P. N. Campbell \& G. D. Greville, vol. 4, p. 106.

SAlser, W., JANIN, J. \& LeVINTHAL, C. (I968). Measurement of the unstable RNA in exponentially growing cultures of Bacillus subtilis and Escherichia coli. J. molec. Biol. 3I, 237.

SCHNEIDER, W. C. (1957). Determination of nucleic acids in tissues by pentose analysis. Meth. Enzymol. $3,680$.

StUBBS, J. D. \& HALL, B. D. (I968). Level of tryptophan messenger RNA in Escherichia coli. J. molec. Biol. 37, 289.

Wehrli, W., KnÜsel, F., Schmid, K. \& Staehelin, M. (1968). Interaction of rifampicin with bacterial RNA polymerase. Proc. natn. Acad. Sci., U.S.A. 6r, 667.

YUDKIN, M. D. (I966). Protein synthesis by long-lived messenger ribonucleic acid in bacteria. Biochem. J. 100, $50 \mathrm{I}$.

YuDkIN, M. D. (1968). Lifetime of messenger ribonucleic acid for penicillinase synthesis in several strains of bacilli. Biochem. J. 108, 675 .

Zimmerman, R. A. \& Levinthal, C. (1967). Messenger RNA and RNA transcription time. J. molec. Biol. 30, 349. 